\title{
Conflicts of Interest in Financial Intermediation
}

Guido Palazzo

Lena Rethel

\begin{abstract}
The last years have seen a surge of scandals in financial intermediation. This article argues that the agency structure inherent to most forms of financial intermediation gives rise to conflicts of interest. Though this does not excuse scandalous behavior it points out market imperfections. There are four types of conflicts of interest: personal-individual, personal-organizational, impersonalindividual, and finally, impersonal-organizational conflicts. Analyzing recent scandals we find that all four types of conflicts of interest prevail in financial intermediation.
\end{abstract}

KEY WORDS: financial intermediation, conflict of interests, principal-agent theory

Shortly after the turn of the millennium, a spate of scandals cast a bad light on financial intermediation and public concern was on the rise. In the U.S., business practices of financial intermediaries such as insurance companies, mutual funds, investment banks and others, and the conflicts on interests they face came under investigation. In both the U.S. and Europe, a series of accounting scandals erupted, Enron and Parmalat probably being the most famous cases. Although accounting firms received the major share of the blame, the fraud could not have happened without the complicity of financial intermediaries. These scandals led to the implementation of regulatory and legislative changes, most prominently the Sarbanes-Oxley Act of 2002. Despite being of particular interest in recent years, work on ethics in finance in general and conflicts of interest in financial intermediation in particular is still sparse. Although the last years have seen a surge in both more theoretical (see e.g., Boatright, 2000, 1999; Crockett et al., 2004; Dobson, 1997, 1993; Walter, 2003) and empirical work (see e.g., Kroszner and Strahan, 2001; Walter, 2006;
Zitzewitz, 2003), the literature is still only emerging. This article seeks to address this deficit on a conceptual level, following Carson's recent plea that "work in business ethics should pay more attention to conflicts of interest, especially the ways in which conflicts of interest are 'internal' to professional roles and pervade business and professional life" (Carson, 2004: p. 179). Our article contributes by clarifying and structuralizing the broad field of conflicts of interest with reference to financial intermediation.

According to Boatright (1999: p. 5f), ethics in finance concerns the financial services industry as well as financial markets and financial management. However, the following discussion is limited to financial intermediation, provided by the financial services industry and financial markets and their related institutions. These are especially prone to structural conflicts of interest as will be illustrated in the following. While Thielemann and Ulrich (2003) propose to differentiate between contractual and non-contractual fields of ethical responsibility in the financial sector, our study looks at the responsibilities that arise in contractual relationships between the financial intermediary and its client(s) and the conflicts that are specific to that relationship. ${ }^{1}$

The rest of the article is organized as follows. (a) Since our analysis of conflicts of interests in financial intermediation builds upon a contractual principal agent relationship, we will begin by introducing the principal agent paradigm. (b) This section is followed by a description of the main actors in financial intermediation. We then propose a structure for the analysis of conflicts of interest and advance examples from recent financial scandals. (c) The concluding section gives a short overview of possible solution mechanisms. 
The principal agent paradigm as context of analysis

A financial intermediary goes between the users and suppliers of financial resources (Carmichael and Pomerleano, 2002), a relationship that can be modeled as a principal agent relationship. The financial intermediary (the agent) acts on behalf of its client (mostly dispersed, uninformed investors the principal) without risking its own assets. Its superior knowledge allows it to act more efficiently and to save costs (e.g., transaction and information costs through specialized technical knowledge and economies of scale). Principal and agent enter a contractual relation in which the intermediary provides certain services - such as transaction and fiduciary services but also advisory and management services - to its client. These services are more or less concretely specified. In return, the client pays the intermediary a fee which might follow a fixed rate or depend on the intermediary's performance.

The model assumes that the principal has an information deficit compared to the agent. Their interests might differ substantially. The agent is usually modeled as a self-interested individual who is trying to maximize profit (see Jensen and Meckling, 1976 for a detailed discussion of the concept). There are three types of problems according to the model: hidden action, hidden knowledge, and hidden information. The first implies that the principal is not able to fully observe the agent's actions and cannot be perfectly monitored (at least not without costs). This might give way to moral hazard on the agent's side. It is not possible to completely specify the contract between principal and agent as not all states of nature are to be fully known ex ante. This problem is aggravated by the fact that there might be information about the contractual environment which is known to the agent but not to the principal (hidden information). The last problem is that of hidden knowledge: some features (e.g., the other clients, compensation scheme of the employees etc.) - or more generally the incentive structure - of the agent are not fully known to the principal and the agent per se has no incentive to disclose them. Building upon this concept of principal-agent theory, we propose two modifications for the application to financial intermediation.

\section{Modification 1, professional ethics}

The relationship between intermediary and client in financial intermediation goes beyond the general principal agent relationship that for instance exists between a manager within a corporation and the owner of a corporation. The agents customarily are held with the legal authority and duty to make decisions regarding financial matters on the clients' behalf. Safeguarding the clients' assets, the financial intermediary has a custodian role with broader public implications. Therefore, it has been argued that professionals in financial intermediation have professional duties in this agency relationship equaling those of, for example, accountants, lawyers, and medical staff. The three features characterizing a profession are, according to Boatright (1999: p. 42), (i) a specialized body of knowledge (ii) a high degree of organization and self-regulation, and finally (iii) a commitment to public service. He comes to the conclusion that although the pursuit of self-interest is more prevailing in financial intermediation, it still requires a special professional ethics due to its fiduciary function. Boatright (1999: p. 6) subsumes the obligations of financial intermediaries under the following: "The main duties of professionals are to perform services with competence and due care, to avoid conflicts of interest, to preserve confidentiality, and to uphold the ideals of the profession". Thus, the agency relationship is intensified by a special trust structure.

\section{Modification 2, increased number of principals}

Standard principal-agent theory was developed to address the problem of diverging interests of the principal and its agent. However, in the case of financial intermediation it is not only the problem of opposing personal interests. There are many cases in which the agent has to act for two principals with possibly diverging if not opposing interests (Bernheim and Whinston, 1986). Thus, it requires some modifications of basic principal-agent theory. The principal can no longer be modeled as a unitary actor. There are two cases that can be distinguished. In the first, the agent sells the same kind of service to different clients. In the second, different kinds of services are offered to different clients. The agent 
faces a problem of how to weigh the different if not opposing interests of the principals and accordingly, how to best act in the interest of all clients.

\section{The landscape of financial intermediation - actors and activities}

Traditionally, capital markets are viewed as means of an efficient allocation of capital in matching capital suppliers (lenders) and users (borrowers). However, capital markets are far from being perfect and thus financial intermediaries are needed to improve the efficiency of capital allocation, for instance by reducing information and/or transaction costs or by creating liquidity (French and Leyshon, 2004). Yet, financial intermediaries as profit-making organizations are more than neutral go-betweens. In the following, the landscape of financial intermediation will be outlined and general characteristics of the actors will be depicted. Figure 1 gives a schematic overview of the agency structure of financial intermediation.

We distinguish between three types of financial intermediaries: institutional investors, 'pure intermediarieśs such as brokers and investment banks, and commercial banks. These institutions have a different standing in financial intermediation.

Institutional investors are relatively close to individual investors (or other institutional investors) and usually do not directly interact with the users of capital (with the exception of venture funds, which invest directly in companies). ${ }^{2}$ Institutional investors aggregate funds from a number of other investors (such as individuals, corporations, gov-

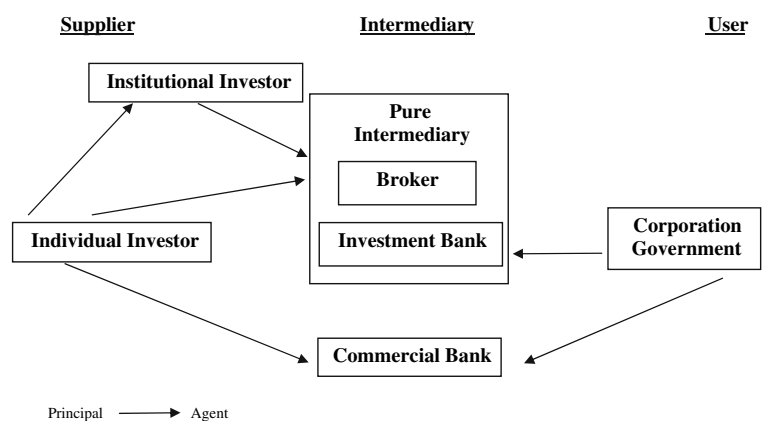

Figure 1. The agency structure: capital suppliers financial intermediation - capital users. ernments, and other institutional investors) and manage them professionally on their behalf. Institutional investors, operating with large amounts of money, allow smaller investors to better diversify risk, a process which is termed 'portfolio transformation' (French and Leyshon, 2004: p. 268). Besides, as operating on an economies of scale basis, institutional investors help to reduce transaction costs (especially trading but also information costs and other costs). They usually make a profit by charging a fee. A defining characteristic is that the risk is still borne by the investor which gives the manager a fiduciary role, acting as an agent in the transactions (Carmichael and Pomerleano, 2002). The following analysis will concentrate on one class of institutional investors in particular, that of mutual funds. In contrast to mutual funds, pension funds as the second most prominent group of institutional investors are heavily regulated if not even managed by public sector entities. Their specific situation gives rise to special problems which we will not address in our article. A mutual fund raises money by selling shares to investors who receive an equity position in the fund and in each of its underlying securities. The fund invests into a group of assets as it is stated by the terms stipulated in the trust deed. The money raised is invested by the fund into a wide range of assets, such as shares, bonds, derivatives, and money market instruments. Typically, shareholders are free to sell their shares at any time, although the price of a share in a mutual fund fluctuates daily, depending upon the performance of the assets held by the fund. The relationship between mutual fund company and investors equals a trust structure. ${ }^{3}$ Above all, their design as long-term savings vehicles gives mutual funds special obligations toward their investors/principals and the wider public in general. However, institutional investors also act as principals insofar as they give orders to brokers and investment banks.

Brokers and investment banks are pure intermediaries inasmuch as they serve to reduce information and transaction costs without transforming the asset class (French and Leyshon, 2004). Investment banks and brokers mediate between buyers and sellers of securities (bonds and shares), the former on the primary market (floating of shares and debt underwriting), the latter on secondary markets (where 
assets are resold and repurchased). An investment bank acts as an underwriter and thus an agent for corporations and governments issuing securities. In addition, they might facilitate mergers and acquisitions, private equity placements and corporate restructuring. They do not have the custodian role of traditional banks or asset managers, but instead certain other obligations toward their clients as, e.g., confidentiality. A broker maintains markets for previously issued securities. Thus, whereas investment banks come from the side of the corporation and should try to make the best deal for their corporate clients (i.e., raising capital to attain the lowest costs), brokers trade on the secondary market and should execute transactions by making the best deals for investors (individual and institutional). Frequently, both give additional advisory services to their clients and both functions (underwriting/ investment banking and broking) are localized in one entity.

Commercial banks accept deposits and make loans thus mediating between borrowers and lenders (Valdez and Wood, 2003). Like institutional investors they transform portfolios by pooling savings for many small depositors and diversifying risk in lending to different institutions and with different maturities. While pure intermediaries act in a rather anonymous context commercial banks tend to build longer-standing relationships (in their role as depository intermediaries as well as lenders). On the one hand, commercial banks have a fiduciary role toward their depositors. Freixas and Rochet (1997) point out that - as they have only a limited knowledge of the safety of financial institutions depositors have to be protected. Banks are meant to overcome imperfect information on borrowers, especially by screening and monitoring loans. On the other hand, commercial banks provide loans to corporations and governments and charge a premium for this service.

The above is only a rough sketch of the agency structure(s) in financial intermediation. In reality the picture is often more complex with many more actors involved. However, as has become apparent even in this simplistic model, a modification of the traditional principal-agent model is justifiable on the grounds of the diverse relationships in financial intermediation. In the next part, we will turn our attention to conflicts of interest in this setting.

\section{A categorization of conflicts of interest}

Having outlined the basic principal-agent theory and its modifications requisite to apply it to financial intermediation and having described the landscape of financial intermediation we will now turn to characterizing the types of conflicts of interest that might or do occur between and within the actors depicted above. To streamline the following discussion, problems which are not specific to the financial industry are left out. This would be, for instance, conflicts of interest in the shareholder - board of directors relationship or the design of "ethical products" (as e.g., socially and ecologically responsible investment in case of financial services).

We will focus on problems in financial intermediation that have come up over the last years and add illustrating examples from the recent spate of financial scandals. Our choice of incidents is ad hoc, based on U.S. Securities and Exchange Commission press releases since the 2000 end of stock market boom and media coverage. However, the foremost aim is to show what types of conflicts of interest systematically prevail in financial intermediation. Conflicts of interest are most prone to appear in unregulated areas, tempting individuals and organizations to exploit loopholes. But as recent corporate scandals show, even in heavily regulated industries such as financial services, they do happen. Modification 1 of the principal-agent model gives rise to conflicts of interest in this relationship as the professional, in this case fiduciary, function of the agent puts her into a position which she can exploit for her own benefit, the textbook definition of conflict of interest (see, e.g., Moore et al., 2006). However, this simple definition hardly does justice to the complexities of conflicts of interests built into the structure of financial intermediation. First of all, it does not differentiate between the existence of a conflict of interest and its exploitation. Second, its characterization of the agent is too vague. Is it the individual professional? Is it the organization she represents and with which the principal most probably has contracted? And third, how do we account for situations in which the agent does not simply pursue her personal gain? Thus, a more systematic, polydimensional approach is required. Boatright (2000: p. 202) defines a conflict of interest as a situation in which "a personal or institutional 
interest interferes with the ability of an individual or institution to act in the interest of another party, when the individual or the institution has an ethical or legal obligation to act in that other party's interest". In the context of the financial services industry, he regards three forms of conflict of interest as relevant:

(1) Actual versus potential conflicts of interest. There are situations in which conflicts of interest are built into the structure of the system, in other words, unavoidable (potential). But it is the concrete misconduct of a person or an organization that turns the systemic/systematic potential into a real act against fiduciary duties (actual).

(2) Individual versus organizational conflicts of interest. An individual conflict of interest is due to a professional's personal behavior, whereas an organizational conflict of interest is due to organizational structure. As a general rule, the more functions an organization performs, the higher the potential for conflicts of interest it entails (Walter, 2003). In the end, it also is the question of who is the agent, e.g., the person in charge of the account or the organization as a whole.

(3) In regard to the modified version of the principal-agent model discussed above, the most important distinction Boatright makes is that between personal versus impersonal conflicts of interest. Exploitation of conflicts of interest is often provoked by the individual gains it promises to individual professionals or organizations, as Carson, 2004: p. 162) puts it, "the temptations to do what we know will violate our duties to other parties". This is in accord with Latham's claim that "a person [or organization] has a conflict of interest when, in the presence of some duty to pursue the interest of another, she is motivated by self-interest to do something inconsistent with this duty" (as quoted in Carson, 2004, p. 163). Thus, personal conflicts of interest occur in the pursuit of self-interest which conflicts with the obligations as agent, the classical situation of the principal-agent model. Yet, while personal conflicts of interest relate to principal-agent conflicts, impersonal conflicts can be understood as arising from principal-principal conflicts, the second modification of the standard principal-agent model discussed above. Impersonal conflicts of interest occur if agents are confronted with conflicting interests of different principals to whom they provide different or similar kinds of services. In other words, conflicting interests of the principals give rise to a conflict of interest for the agent. Thus, again, this type of conflict of interest is rooted in the structure of the system. ${ }^{4}$

Boatright argues (2000) that most conflicts of interest in the financial service industry are potential instead of actual. Despite the recent corporate scandals, real misconduct can be regarded as the exception. We will start the following analysis with the latter two aspects, personal/impersonal and individual/organizational in order to reconstruct the different possible forms of conflicts of interest that occur in the financial services industry along the latter two differentiations made by Boatright. We will come back to the actual/potential aspect in our concluding discussion on the transition from legal/moral to illegal/immoral behavior along individual or organizational conditions and possible forms of prevention.

Cross-classifying the categories personal/impersonal and individual/organizational leads us to consider the following four combinations of conflicts of interest: (a) personal-individual, (b) impersonalindividual, (c) personal-organizational, and finally (d) impersonal-organizational (Table I). While Boatright (2000) assumes that most conflicts of interest in financial services are impersonal and organizational, we will demonstrate on the basis of recent scandals that all four conflicts systematically prevail in financial intermediation.

\section{Personal-individual conflict}

Conflicts of interest can arise from personal trading. As a matter of fact, personal trading has given rise to a series of misconducts over recent years, ranging from price manipulations over false statements to misuse of sensitive information. However, in this discussion 


\section{TABLE I}

Categorization of conflicts of interest according to principal-agent model

\begin{tabular}{lll}
\hline Conflict of interest & \multicolumn{1}{c}{ Individual } & \multicolumn{1}{c}{ Organizational } \\
\hline Personal & $\begin{array}{l}\text { Arises in the relationship } \\
\text { between individual professional } \\
\text { and her principal. }\end{array}$ & $\begin{array}{l}\text { Arises in the relationship between } \\
\text { (multi-purpose) organization and principal. }\end{array}$ \\
$\begin{array}{l}\text { Arises from the conflicting interests } \\
\text { of principals faced by the individual } \\
\text { professional. }\end{array}$ & $\begin{array}{l}\text { Arises from the conflicting interests } \\
\text { of principals faced by the (multi-purpose) } \\
\text { organization. }\end{array}$ \\
\hline
\end{tabular}

we want to concentrate on two cases that occur within a principal agent relationship (between client and financial intermediary), self-dealing of mutual fund managers and broker insider trading. Given the huge amounts of money they invest, mutual fund managers influence the prices of assets by trading on behalf of the fund or even by the mere public announcements by which they recommend assets or caution about them. Self-dealing in these assets might induce managers to put their own interests above that of the fund's investors. Therefore, it can be qualified as a personal-individual conflict. Yet, problems with personal trading also arise within other financial intermediaries as is the case, for instance, when a broker not only executes trades for his clients but also on his own behalf on information from clients.

The heavy regulation of financial services and in particular brokerage and mutual fund activities might reduce, but cannot preclude the occurrence of personal-individual conflicts of interest. In 2006, the SEC filed for settled enforcement action against Broker-Dealer Friedman, Billings, Ramsey \& Co. for unlawful insider trading (SEC Press Release 2006-214). In the same year, Morgan Stanley was charged with failure to maintain and enforce policies to prevent misuse of inside information (SEC Press Release 2006-103). Goldman Sachs and Merril Lynch are two other investment banks where personnel was involved in insider trading (SEC Press Release 2006-53). In a high profile case, the SEC brought enforcement actions against Putnam Investment Management, one of the largest mutual fund companies in the U.S.A., and two of its managing directors for self-dealing in 2003 (CBSnews.com, 2003; SEC Press Release 2003-142).
These incidences also indicate that current (SEC) regulation does not always successfully prevent the exploitation of conflicts of interest. Another kind of personal-individual conflict of interest can exist in the relationship between underwriter and municipal government client and is often referred to as yield burning, a practice which came to the attention of the U.S. regulatory authorities in the mid-1990s foremost because of tax reasons (Dodd, 2003). Yield burning occurs when underwriters in advance refundings impose markups on tax-exempt U.S. Treasury bonds deposited to compensate investors after the refunding bonds have been issued. The markup can divert money away from the municipality into the pockets of the underwriter, the exploitation of a typical personal-individual conflict of interest. In a global settlement with the SEC in April 2000, seventeen brokerage firms agreed to pay more than $\$ 139$ million (SEC Press Release 2000$45)$. In addition, more than $\$ 18$ million were to be paid directly to municipalities. Again, some of the biggest investment banks were involved.

Another kind of personal-individual conflict of interest that arises from IPO activities is laddering. Laddering describes investment bank's or investment bankers' efforts to motivate clients to buy IPO shares in the first days of trade (the after market that immediately follows the IPO) by promising preferential treatment in the share allocation of future IPOs, thus making the IPO a bigger success. In the recent wave of financial scandals, Morgan Stanley, for instance, has been found to be involved in laddering with some of its most important investment clients (Smith, 2003). Laddering, it seems, has become a widespread practice. A litigation on laddering at the New York stock exchange includes more 
than 50 investment banks and 309 IPOs between 1998 and 2000 (Chavous et al., 2004). Laddering is a personal-individual type of conflict of interest as this fraudulent behavior benefits the organization if not even single employees without deceiving other clients with which the investment bank has a (current) contractual relationship.

\section{Impersonal-individual conflict}

Especially since 2003, attention has turned to problems in the mutual fund industry as recent financial scandals centered around market timing and late trading practices (Economist, 2003b; SEC Press Releases 2000-2007). Both forms of conflict have their roots in the fund industry's convenience of evaluating fund shares. Prices of fund shares usually are fixed once a day, in the U.S. at 4 p.m. New York time. As the underlying assets are more volatile, the prices of the fund and its underlying assets might differ throughout the day. Market timing refers to the practice of buying and selling fund shares very rapidly, thus taking advantage of shortterm fluctuations in the fund's underlying portfolio (e.g., by reacting to information from foreign markets that is not taken into account by pricing the fund's shares). These activities are opposed to a mutual fund's design as a long-term investment vehicle as they force it to remain more liquid than it would otherwise be, reducing its performance. As Mahoney (2004: p. 174) emphasizes, it is mainly the "deliberate attempt to exploit stale prices [...that] defines 'impropeŕ market timing". Zitzewitz (2003) estimates that market timing leads to losses of about USD 5 billion for ordinary, long-term investors per year. Condoning market timing has turned out to be expensive for mutual funds. Settlements reached with the SEC are often in the eight-digit range if not even higher. In an extraordinary case, Prudential agreed to pay $\$ 600$ million to settle fraud charges in connection with deceptive market timing of mutual funds (SEC Press Release 2006-145).

Allowing favored investors to trade after the new fixing of the price but at the previous conditions, is called late trading and usually illegal. However, in more than a third of cases it went hand in hand with market timing, done by some larger investors with the support of fund management (SEC Press
Releases 2003-February 2007). These practices usually occur as a favor to big (i.e., mostly other institutional) clients, damaging small investors. Thus, clients with different bargaining power are treated differently. These conflicts of interest are impersonal-individual in so far as it were mostly single professionals participating in the agreements (and does not relate to organizational structure) though it was usually condoned if not encourage by organizations.

A third example of impersonal-individual conflicts is spinning. Spinning describes the practice of investment banks to distribute highly sought after shares among preferential clients, to attract future underwriting business. Credit Suisse First Boston and others have been involved in a recent scandal of spinning, offering corporate executives preferred access to shares in IPOs in hopes of getting some investment banking business in return (Smith et al., 2003). In 2002, it took CSFB $\$ 100$ million to settle these charges (SEC Press Release 2002-14). Solomon offered Bernard Ebbers, the former CEO of WorldCom Inc., a preferred access to a widely oversubscribed telecommunication IPO in 1999. Ebbers sold the shares within days and made a profit of more than $\$ 11$ million. WorldCom Inc. at that time was an investment banking client of Solomon (Craig, 2002). This conflict of interest is impersonalindividual in so far as that preferential treatment was given to certain clients above others to increase the firm's future profits. Firms sued for abusive or unlawful IPO practices over the last years include Morgan, Stanley, Goldman Sachs, J.P. Morgan and CSFB, again some of the industry's best and bravest.

\section{Personal-organizational conflict}

Conflicts of interest can occur in the context of fund share evaluation or the cost structure of a fund and the investor-mutual fund-broker relationship. Fees and expense ratios are not always disclosed in detail which leaves the investor ignorant of the amount paid for the fund's management. This allows fund management to bundle commissions and to pay for the trades executed by stockbrokers with soft commissions. Those are payments to brokers in exchange for research and other services besides trade execution, including trading or information systems and 
preferential treatment in initial public offerings whose costs are passed on to the clients (Schwartz and Steil, 2002). Instead of adding them to the management fees, they show up in a lower performance of the fund, thus giving a more competitive picture of the fund's fee structure. Similarly, directed brokerage, giving trades to preferred brokers can ensure preferential treatment of (certain) mutual funds. Another frequent misconduct are payments for shelfspace, the use of both hard payments and directed brokerage to secure heightened visibility of funds' products within a brokerage's distribution networks (from the broker's perspective, this type of conflict of interest could also be classified as impersonalindividual as certain clients are treated better than others to increase revenues). In a settlement with the SEC, Morgan Stanley, charged with inadequate disclosure in mutual fund sales by receiving this kind of payment from mutual funds, paid $\$ 50$ million in November 2003 (SEC Press Release 2003-159). A few months later, MFS paid a penalty of $\$ 50$ million for its shelf-space arrangements with brokerage firms (SEC Press Release 2004-44). Recent findings show that even after subtracting the costs of 'soft' services, trading costs are higher than necessary which might be acerbated by the fund manager's incentive to increase the frequency of trades (Schwartz and Steil, 2002: p. 45). This type of conflict is personal-organizational as it is caused by the profit-making aims of the fund management, embedded in the organizational structure of soft payments.

Analysts' research is another source of personalorganizational conflict of interest. In April 2003, shortly before the mutual fund scandals erupted, 10 big Wall Street investment banks settled with the SEC and other U.S. regulators by paying USD 1.4 billion (SEC Press Release 2003-54). Charges were inadequately supervised research and investment operations (Economist, 2003a). Star analysts such as Jack Grubman of Solomon and Henry Blodget of Merril Lynch were accused of being involved in fraudulent research reports and barred from the securities industry (SEC Press Release 2003-55; 2003-56). Within Merrill Lynch e-mail traffic documented that analysts called stock 'crap' and 'junk' internally but praised it externally (Frieswick, 2002). At the same time, Morgan Stanley was accused for having built too strong incentive links between investment business and the research department (Smith et al., 2003). For misleading investors through dubious research, Morgan Stanley paid $\$ 125$ million for settling the charges (Solomon, 2003). These are only some of the charges that have been brought up in the last few years. To be able to give advisory services, these institutions often rely on their internal research departments. This structure provides for conflicts: analysts' research, especially their earnings forecasts might be influenced by their desire to attract investment banking clients. This problem in reality has been acerbated by wrong incentives laid out in the compensation structure. Analysts' bonuses in many cases used to depend on the overall performance of the firm, or even worse, on underwriting profit. In fact, Chan et al. (2003) find that analyst's earnings forecasts are influenced by their desire to attract investment banking clients. However, they add that this effect is mitigated in international markets. This is a personal-organizational type of conflict of interest that is inherent in the firm's organizational structure. Analysts might have access to insider information due to their firm's involvement in investment banking procedures and exploit this knowledge for their organization's profit (or their own via the mechanism of compensation schemes).

\section{Impersonal-organizational conflict}

Connected lending describes a conflict of interest in the context of a commercial bank's function of accepting deposits and making loans. This signifies that banks are simultaneously lenders and borrowers, which is a potential source for conflict of interest in itself. However, in many cases they assume additional functions such as monitoring the loans granted and advisory services to debtors. This might result in having a position in the board of the debtor company, a case that is referred to as connected lending. Those board connections provide an area of conflict. Though they help monitoring (and reducing the costs of information), the lending policy might become biased as connected loans might be treated more favorably (e.g., by better conditions for rolling over debts). It is a impersonal-organizational type of conflict of interest in two respects. On the one hand, corporate clients are given preferential treatment over depositors. This conflict is due to the different 
services a bank provides. The monitoring efficiency argument does not hold in cases where connected lending leads to sup-optimal debt recovery policies as, for example, holding on to bad borrowers. On the other hand, among the borrowers, those with board connections are favored. Kroszner and Strahan (2001) find that board linkages are frequent in the U.S. However, they conclude that there is sufficient regulation to avoid potential conflicts of interest in the U.S.A. as opposed to the situation in countries with weaker financial regulation. However, as we have demonstrated in the discussion above, regulation does not always help to prevent the exploitation of conflicts of interest.

Table II reflects the types of conflict that occur along our proposed matrix. Having dealt with those sub-entities in financial intermediation the reader might ask what happens in the case of universal banking and financial conglomerates. Roughly defined in this context, a universal bank unites all the above-characterized roles and functions and more. Consequently, it provides a vast field for (potential) conflicts of interest in its organizational structure. However, most of the concrete problems that are to arise have already been discussed related to the other intermediaries. Thus, we will not analyze universal banking separately (for more detailed information about conflicts of interest in universal banks and a regulatory history of universal banking in the U.S. we refer to Crockett et al., 2004).

As this discussion has shown, conflicts of interest in financial intermediation are systemic. Therefore, as Boatright argues $(2000$, p. 2001), the challenge "is not to prevent conflicts of interest in financial services but to manage them in a workable financial system". In order to manage them, one must be capable of understanding them. Our categorization might serve to clarify the characteristics of the forms of conflict that prevail. By unfolding the individual and organizational roots behind the various forms of conflict of interest, the categorization may help to develop strategies to cope with the unavoidable risks of their exploitation. We will conclude our article by a short discussion on the third form of conflicts of interest, actual and potential conflicts of interest.

\section{Keeping potential conflicts potential - the driving forces of ethical decision-making}

Trevino (1996) has argued that ethical decisionmaking has to be analyzed along individual and organizational/situational lines. This resonates with our own analysis. As we have argued in the above discussion, there are two major roots of conflicts of interest: those for which the standard principal agent paradigm applies and those arising in a slightly modified setting with two or more principals. In the latter case, agents are tempted to better serve the interests of some of their principals than others. This may lie in the individual interest of the intermediary or one of its employees or be due to the organizational structure.

Conflicts of interest are inherent in the system. While the exploitation of conflicts of interest can be criticized, their mere existence can neither be condemned per se nor be avoided without great difficulty or negative side effects for the efficiency of

TABLE II

Types of conflicts of interest

\begin{tabular}{lll}
\hline Conflict of interest & \multicolumn{1}{c}{ Individual } & \multicolumn{1}{c}{ Organizational } \\
\hline Personal & $\begin{array}{l}\text { Personal trading/Self-dealing/ } \\
\text { Insider trading } \\
\text { Yield burning }\end{array}$ & Soft commissions \\
& & $\begin{array}{l}\text { Directed brokerage/Improper } \\
\text { marketing arrangements/ "Shelf space" } \\
\text { payments } \\
\text { Analyst research }\end{array}$ \\
Impersonal & Laddering & Connected lending \\
& Market timing & \\
Late trading & \\
& IPO allocation practices/Spinning & \\
\hline
\end{tabular}


financial intermediation. Individuals and organizations alike have to make their own judgments to find ways to cope with the potential transition from potential to actual conflicts of interest. Generally, a deeper understanding of conflicts of interest depends on sufficient insights into the various dimensions that influence ethical and unethical decision-making. If the assumption is true that these conflicts cannot be avoided, the question remains of how actors that are confronted with such a conflict make their decision and how the ethicality of these decisions can be improved. What can be done to deal with the systemic compliance and integrity threats that are, for instance, linked to asymmetric information or bargaining power? What provokes the actual misconduct of and within organizations?

Bazerman et al. (1998) have discussed conflicts of interest as competing internal preferences. Actors are torn between something they want to do and something they should do. Such a conflict between interests and values seems to be of particular relevance in personal conflicts of interest: An agent has to choose between her interest and a duty toward her principal. Impersonal conflicts of interest seem to follow a different logic. Since they describe a principal-principal dilemma, they seem to emerge from conflicting duties with unclear priorities. Adopting the argument of Bazerman et al. (1998) there seem to be divergent "shoulds" at stake. Badaracco (1997) has argued that in such a dilemma, values collide with values.

How do actors behave in these two different types of conflict of values against interest and values against values? One alternative is to answer this question by referring to characteristics of the individual. As Solomon has for instance argued, the integrity of individual decision-making depends on the ability to perceive one's action as embedded in an overarching normative context (1993). The ability of such a communitarian thinking depends on the individual virtuousness (Caza et al., 2004) and is expressed in the individual ability of moral reasoning (Solomon, 1993). Weber has followed this assumption in his adoptation of Kohlbergs model of moral development in managerial decision-making (Weber, 1991). Within such a concept, actors get corrupted because of their character. They are 'bad apples in the (otherwise good) barrel' that give priority to self-interest. However, such an approach is limited for at least two reasons. First, it does not help to explain (and manage) impersonal conflicts. Second, it does not explain, why good managers do bad things. As Badaracco and Webb (1995) have for instance shown, young managers often feel pressured to act unethically. This does not necessarily come from their own preferences but rather from organizational pressure. Zimbardo's prison experiments from the 1970s clearly demonstrate that good people might do evil things if they are put in an evil context (Zimbardo, 2004, 2007). In this case, it seems to be the rotten barrel that influences the quality of the apples. When Zimbardo asked average students to roleplay prisoners and guards, they started to behave and to feel like prisoners and guards. Greenberg (1993) examined the immoral behavior paradox which is based on moral reasoning: The perception of being treated unfairly is used as a means of justifying striking back or rebalancing giving and taking (see also Blader and Tyler, 2003). Furthermore, intercultural differences are important for the understanding of conflicts of interests. This is especially important for situations, where actors perceive a collision of values. In a communitarian society, where individuals are embedded in strong networks of obligations and relationships (Jackson, 2000) the decisions made will probably differ from those made by individuals in a more individualistic cultural context. While individualistic societies operate with a universal approach to ethical dilemmas (HampdenTurner and Trompenaars, 1993), actors with strong perceptions of communitarian obligations might have less difficulties to give illegal advantages to members of their ingroups. On the contrary, a special treatment because of strong social ties might even be an expectation of the investors. The level playing field that is important for individualistic societies might be considered as unethical in communitarian societies.

These different findings show that unethical behavior might depend on the design of the context and/or the perception of the context by the actor. Contextual factors, therefore, might influence individual decision-making in two forms. First, organizations might create a context, in which unethical behavior is promoted and agents give preference to their own interests over their duties toward principals. Such an effect might for instance be provoked by reward systems (James, 2000; Jansen and Von Glinow, 1985) or by the behavior of the leaders (e.g., Dickson et al., 2001). Second, organizations might create a context, in which colliding "shoulds" are not clearly 
managed. Organizations have been analyzed as networks of shared meaning with meaning being transmitted through the "use of a common language and everyday social interaction" (Walsh and Ungson, 1991: 60, see also Smircich and Stubbart, 1985). If the shared mental frames do not dispose of a non-ambigious interpretations of conflicts of interest, if there are no clear rules of how to deal with diverging duties, norms and loyalities, employees are exposed to a high ethical ambivalence (Jansen and Von Glinow, 1985). Of course, corporations unavoidably operate in ambivalent contexts with contradictory interpretations of reality (Weick, 1995). But if roles and responsibilities are not clearly defined, there is a high risk of bad behavior that results from a too narrow interpretation of situations. The ambivalence might result from a lack of imagination of the leaders within the organization (who might change the level of ambivalence) or from the intention to motivate employees to walk the thin line between legal and illegal as in the case of Enron.

Therefore, corporate integrity does not solely depend on its numerous actors' correct ethical decision-making at all hierarchical levels. It furthermore depends on the design of the context in which those actors are embedded while making decisions and a sensitivity for the perception of that context by the employees. The successful management of conflicts of interest has to include (at least) the following aspects:

(1) Potential delinquents who have a predisposition for deviant behavior have to be kept in check.

(2) Reward systems and leadership behavior should not promote deviant behavior of otherwise good employees.

(3) The rules of the game must be clear and there should be no (intentional or unintentional) normative ambivalence between official societal norms and informal organizational counternorms.

\section{Fighting legal and ethical misconduct}

The following sub-sections briefly touch on three prominent remedies (see Boatright, 2000 and
Crockett et al., 2004), market discipline, disclosure, and market conduct rules (self-imposed or by government regulation). Stating the limits of a merely compliance-driven approach to conflicts of interest, we additionally discuss integrity-driven activities, which corporations in the financial industry might adopt or strengthen.

\section{Competition and market discipline}

Competition among providers of financial intermediation helps in avoiding conflict of interest as it increases clients' bargaining power. However, though this is true in the standard principal agent setting (where many agents compete for the attention of one principal), it does not necessarily respond to the above-described concrete decisionmaking situations with more than one principal. In these situations, principals compete for the attention of the agent. Besides, competition among agents remains limited. Though, for instance, in the case of broker commissions, increasing competition is related to reduced (transaction) fees, in many cases the missing transparency of structures prevents workable competition and weakens the disciplinary power of the market. An example is the opaque cost structure of mutual funds. Furthermore, cost structures of competing mutual funds are difficult to compare. Thus, cost structures are not clear to the clients who might not be able to choose the best service. As we have seen in the case of soft commissions, it might even lead to perverted outcomes, where the competitive pressure provokes the agents to increase the client's disorientation and thus creates additional room for conflicts of interest.

\section{Disclosure}

Market discipline visibly is not sufficient to manage conflicts of interest as demonstrated above. This points toward the important role of disclosing possible and actual conflicts of interest. By making colliding interests known to their clients and disclosing internal structures (as cost structures and compensation schemes), financial intermediaries can take a proactive stance in avoiding conflicts of 
interest. However, even voluntary disclosure is not sufficient. On the one hand, many investors are not well informed nor interested in particulars. This could result in an inability to understand the significance of disclosed fields of tension. On the other hand, and this is even more probable, only a few firms would be prepared to take this proactive stance, fearing competitive disadvantages compared to other intermediaries that remain silent about potential conflicts. In addition, many actors lack moral motivation. As we have seen, it is quite easy in many cases to tell whether a behavior is adequate or inadequate (which does not necessarily mean illegal). However, some intermediaries actually seem to specialize on exploiting regulatory loopholes and acting in gray areas. Depending on the goodwill of financial intermediaries apparently is not enough.

\section{Market conduct rules and regulation}

To create a level playing field, disclosure should be made mandatory for all market participants. Increased transparency can result from industry self-regulation or government legislature. In most countries, this is done in a two layer system: selfregulation institutions that are overseen by the state. Apart from rendering disclosure obligatory, regulation has an important role in setting standards but also must be endowed with power to enforce its principles. The heaviest form of government regulation is to mandate structural reforms. In the U.S., this was first introduced by the 1933 Banking Act (also known as Glass-Steagall Act), which separated commercial banks from investment banks/brokerages to reduce conflicts of interest. Recently, in the U.S., separatist tendencies have been reinforced by the Sarbanes-Oxley Act of 2002, a counterreaction to what Stiglitz (2003, p. 87) terms the 'deregulation run amok' experience of financial sector liberalization in the U.S. in the 1990s which culminated in the Financial Services Modernization Act (also known as Gramm-Leach-Bliley Act) which repelled the structural barriers of the Banking Act as it permits banks, securities firms and insurance companies to affiliate under the structure of a financial holding company (Crockett et al., 2004). Sarbanes-Oxley, though mainly concerned with auditing practices, prescribes an internal separation - a Chinese wall between research and investment banking activities and thus reimposes structural separation between these activities (Section 501 Sarbanes-Oxley Act). However, claims that the provisions of SarbanesOxley impede the efficiency of financial intermediation and disadvantage the U.S. as a financial center amount, which already led to a revision of implementation of Sarbanes-Oxley based legislation and regulation and may lead to a further weakening of the Act (Wighton, 2007). Overall, the effectiveness of the Act in preventing future market misbehavior is questionable (Whalen, 2003) as it addresses only some of the relevant concerns (Suchan, 2004). Nevertheless, it is difficult for governments to regulate financial intermediation in a proactive way. Banner (1997) shows that over the last 300 years of Anglo-American securities regulation often was the result of major crises, and thus reactive. Similarly, in the current time of heightened financial globalization, domestic regulatory bodies and legislation struggle to effectively regulate transnational corporations (Scherer et al., 2006). Furthermore, even in situations where the exploitation of conflicts of interest is clearly illegal, it does happen, not only in small firms, but in some of the industry's biggest players as demonstrated in the above-discussed examples. Thus, the main responsibility in providing a viable financial system still lies with financial intermediaries themselves. A corporate culture has to be established that makes the exploitation of conflicts of interest normatively unacceptable.

\section{Integrity programs}

There are no ready-made remedies for each type of conflict of interest. Obviously, only a combination of mechanisms can sufficiently deal with them. Given the above outlined various driving forces of conflicts of interest, coercive control via laws, market mechanisms, and internal codes can only be part of the answer. In fact, these remedies might help to keep in check some forms of criminal behavior but blind out or even paradoxically provoke other forms. Coercive control might for instance lead to an atrophy of compe- 
tence and thereby increase the ambivalence of the decision-making (Stansbury and Barry, 2007). An overly focus on structural remedies might provoke an underestimation of psychological factors that drive the actors' perception of their situation, the role of leadership example or the relevance of individual ethical empowerment. Paine (1995) has pointed to the limits of a merely law and control-driven ethics program (compliance) and proposed a valuebased approach that rather builds upon creating and fostering a moral climate of shared values (integrity). The idea behind her proposal is the assumption that intrinsically motivated employees might show a more stable and calculable behavior than those employees who are trained to follow legal demands and who feel threatened by sanctions. Explicit incentives or sanctions can even lead to an erosion of the moral climate, e.g., by reducing the level of mutual trust (Frey, 1997). Distrust toward employees that is displayed in sophisticated control and monitoring mechanisms can become self-fulfilling and provoke the very behavior the mechanisms seek to prevent (Ghoshal and Moran, 1996). Integrity programs are strongly linked to the example and commitment of top management (Weaver et al., 1999). Integrity does not replace compliance but strengthens its effects. "Case-based research and theoretical research have suggested that value-oriented programs or combined values and compliance programs should be more effective" (Weaver et al., 1999, p. 55).

A wide range of conflicts of interest exists in the contractual relationships of financial intermediation. Principal-agent theory and its modifications provide a relatively good analytical tool to explain the underlying tensions and to classify the conflicts that arise. However, there is no standard solution to these problems and regulatory tools are consequently diverse. More research has to be carried out to better tailor regulation. Nevertheless, the actors involved in financial intermediation themselves have to act to reduce the potential for conflicts. On the one hand this implies that investors should not blindly trust their agents or, even worse, allow for shady practices as long as the gain is sufficient. It has been very characteristic that most of the scandals have erupted after markets have gone down. On the other hand, financial intermediaries should be fully aware of their special trust position. Accordingly, organizations - as well as the individuals in them - should act with the necessary due diligence and take a proactive role in managing conflict. ${ }^{5}$

\section{Notes}

1. Thielemann and Ulrichs (2003) extensive discussion of non-contractual problems is due to the fact that they analyse the Swiss financial industry with its specifics such as bank secrecy and the non-criminaliation of tax evasion.

2. At least not regarding the funding decision. However, institutional investors are becoming increasingly salient shareholder activists.

3. In some countries the fund management is independent from the company which sells the shares - acting purely in an oversight role - as trust and management function are separated by the law (Carmichael and Pomerleano, 2002).

4. However, deviating slightly from Boatright's taxonomy, we would argue that actual impersonal conflicts do not preclude that individual or organizational actors are also driven by personal gains. This becomes especially relevant in the transition from potential to actual conflict of interest.

5. Both authors contributed equally.

\section{References}

Badaracco, J. L.: 1997, Defining Moments. When Managers Must Choose Between Right and Right (Harvard Business School Press, Boston).

Badaracco, J. L. and A. P. Webb: 1995, 'Business Ethics: A View from the Trenches', California Management Review 37(2), 8-25.

Banner, S.: 1997, 'What Causes New Securities Regulation? 300 Years of Evidence', Washington University Law Quarterly 75, 849-55.

Bazerman, M. H., A. E. Tenbrunsel and K. WadeBenzoni: 1998, 'Negotiating With Yourself and Losing: Making Decisions With Competing Internal Preferences', Academy of Management Review 23(2), 225-241.

Bernheim, V. L. and M. D. Whinston: 1986, 'Common Agency', Econometrica 54(4), 923-942.

Blader, S. L. and T. R. Tyler: 2003, 'What Constitutes Fairness in Work Settings? A Four-Component Model of Procedural Justice', Human Resource Management Review 12, 107-126.

Boatright, J. R.: 1999, Ethics in Finance (Blackwell Publishers, Malden, MA).

Boatright, J. R.: 2000, 'Conflicts of Interest in Financial Services', Business and Society Review 105(2), 201-219. 
Carmichael, J. and M. Pomerleano: 2002, The Development and Regulation of Non-Bank Financial Institutions (The World Bank, Washington, DC).

Carson, T. L.: 2004, 'Conflicts of Interest and Self-dealing in the Professions. A Review Essay', Business Ethics Quarterly 14(1), 161-182.

Caza, A., B. A. Barker and K. S. Cameron: 2004, 'Ethics and Ethos: The Buffering and Amplyfing Effects of Ethical Behavior and Virtuousness', Journal of Business Ethics 52, 169-178.

CBSnews.com (2003) 'Senators Slam SEC In Funds Scandal'. November 3.

Chan L. K. C., J. Karceski and J. Lakonishok: 2003, 'Analysts Conflicts of Interest and Biases in Earning Forecasts', NBER Working Paper No w9544.

Chavous J. D., Maulbetsch, S. Pferdekämper and M. Frantz: 2004, 'Investment Banking Exposure', American Re research paper. http://www.amre.com/content/iw/ invest_bank_exp.pdf. Accessed May 2, 2005.

Craig S.: 2002, 'Offerings Were Easy Money for Ebbers', Wall Street Journal 2 September.

Crockett, A., T. Harris and F. S. Mishkin: 2004, Conflicts of Interest in the Financial Services Industry: What Should We Do About Them? (Centre for Economic Policy Research, London).

Dickson, M. W., D. B. Smith, M. W. Grojean and M. Ehrhart: 2001, 'An Organizational Climate Regarding Ethics: The Outcome of Leader Values and the Practices That Reflect Them', Leadership Quarterly 12, 197-217.

Dobson, J.: 1993, 'The Role of Ethics in Finance', Financial Analysts Journal 49(6), 57-61.

Dobson, J.: 1997, 'Ethics in Finance II', Financial Analysts Journal 53(1), 15-25.

Dodd A.: 2003, 'Valuation of Government Securities Yield Burning'. Tax Exempt Bond Abusive Tax Transactions, Internal Revenue Service, US Department of the Treasury, pp.107-121 http://www.irs.ustreas.gov/pub/ irs-tege/teb2a03.pdf. Accessed February 10, 2007.

Economist : 2003, 'Revolting Shareholders', May 22nd, 2003.

Economist : 2003a, 'The Shakedown Continues', June 27 th, 2003.

Economist : 2003b, 'Perils in the Savings Pool'. Nov. 6th, 2003.

Freixas, X. and J.-C. Rochet: 1997, Microeconomics of Banking (The MIT Press, Cambridge, Massachusetts).

French, S. and A. Leyshon: 2004, 'The New, New Financial System? Towards a Conceptualization of Financial Reintermediation', Review of International Political Economy 11(2), 263-288.

Frey, B. S.: 1997, Not Just for the Money: An Economic Theory of Personal Motivation (Edward Elgar, Cheltenham, UK).
Frieswick K.: 2002, 'More bricks in the wall', CFO Asia, November 2. http://www.cfoasia.com/archives/ 200211-03.htm, accessed May 17, 2005.

Ghoshal, S. and P. Moran: 1996, 'Bad for Practice: A Critique of the Transaction Cost Theory', Academy of Management Review 21(1), 13-47.

Greenberg, J.: 1993, 'Stealing in the Name of Justice: Informational and Interpersonal Moderators of Theft Reactions to Underpayment Inequity', Organizational and Human Decision Processes 54, 81-103.

Hampden-Truner, Ch. and A. Trompenaars: 1993, The Seven Cultures of Capitalism. Value Systems of Creating Wealth in the United States, Japan, Germany, France, Britain, Sweden, and the Netherlands (Currency Doubleday, New York).

Jackson, T.: 2000, 'Management Ethics and Corporate Policy: A Cross-Cultural Comparison', Journal of Management Studies 37(3), 349-369.

James, H. S., Jr.: 2000, 'Reinforcing Ethical Decision Making Through Organizational Structure', Journal of Business Ethics 28, 43-58.

Jansen, E. and M. A. Von Glinow: 1985, 'Ethical Ambivalence and Organizational Reward Systems', Academy of Management Review 10(4), 814-822.

Jensen, M. C. and W. H. Meckling: 1976, 'Theory of the Firm: Managerial Behavior, Agency Costs and Ownership Structure', Journal of Financial Economics 3, 305-360.

Kroszner R. S. and P. E. Strahan: 2001, 'Throwing Good Money After Bad? Board Connections and Conflicts in Bank Lending', NBER Working Paper No w8694.

Mahoney, P. G.: 2004, 'Manager-Investor Conflicts in Mutual Funds', Journal of Economic Perspectives 18(2), 161-182.

Moore, D. A., P. E. Tetlock, L. Tanlu and M. H. Bazerman: 2006, 'Conflicts of Interest and the Case of Auditor Independence: Moral Seduction and Strategic Issue Cycling', Academy of Management Review 31(1), 10-29.

Paine, L. S.: 1995, 'Managing for Organizational Integrity', Harvard Business Review 72(2), 106-117.

Scherer, A. G., G. Palazzo and D. Baumann: 2006, 'Global Rules and Private Actors. Towards a New Role of the TNC in Global Governance', Business Ethics Quarterly 16, 505-532.

Schwartz, R. A. and B. Steil: 2002, 'Controlling Institutional Trading Costs', Journal of Portfolio Management 28(3), 39-50.

Smircich, L. and C. Stubbart: 1985, 'Strategic Management in an Enacted World', Academy of Management Review 10, 724-736.

Smith R.: 2003, 'Morgan Stanley is informed by SEC it may face charges', Wall Street Journal 14 April. 
Smith R., S. Craig and D. Solomon: 2003, 'Wall Street firms to pay $\$ 1.4$ billion to end inquiry', Wall Street Journal 29 April.

Solomon, R. C.: 1993, Ethics and Excellence (Oxford University Press, Oxford, UK).

Solomon D.: 2003, 'Deals and Deal Makers: Morgan Stanley remarks draw criticism by SEC', Wall Street Journal 2 May.

Stansbury, J. and B. Barry: 2007, 'Ethics Programs and the Paradox of Control', Business Ethics Quarterly 17(2), 239-261.

Stiglitz, J. E.: 2003, The Roaring Nineties: Seeds of Destruction (Allen Lane, London).

Suchan S. W.: 2004, 'Post-Enron: U.S. and German Corporate Governance'. Cornell Law School. Cornell Law School LL.M. Papers Series 4, http://1sr.nellco.org/cornell/lps/papers/4. Accessed April 30, 2005.

Thielemann, U. and P. Ulrich: 2003, Brennpunkt Bankenethik: Der Finanzplatz Schweiz in wirtschaftsethischer Perspektive (Haupt, Bern).

Trevino L. K.: 1996, 'Ethical Decision Making in Organizations: A Person-Situation Interactionist Model', Academy of Management Review 11(3), 601-617.

U.S. Securities and Exchange Commission: 2000-2007, Press Releases, http://www.sec.gov/news/press. shtml. Accessed February 10, 2007.

Valdez, S. and J. Wood: 2003, An Introduction to Global Financial Markets 4 (Palgrave Macmillan, Basingstoke, Hampshire).

Wahlen, C.: 2003, 'Revisiting Sarbanes-Oxley', The International Economy 17(4), 40-43.

Walsh, J. P. and G. R. Ungson: 1991, 'Organizational Memory', Academy of Management Review 16, 57-91.

Walter I.: 2003, 'Conflicts of Interest and Market Discipline Among Financial Services Firms'. Paper presented at Federal Reserve of Chicago - Bank for International Settlement conference on "Market Discipline: Evidence Across Countries and Industries", October 30-November 1. http://pages.stern.nyu.edu/ iwalter/, accessed February 11, 2007.

Walter I.: 2006, 'Reputational Risk and Conflicts of Interest in Banking and Finance: The Evidence So
Far'. Working Paper, http://papers.ssrn.com/sol3/ papers.cfm?abstract_id $=$ 952682\#PaperDownload, accessed February 11, 2007.

Weaver G. R., L. K, Trevino, Cochran P. L. (1999) Corporate Ethics Programs as Control Systems: Influences of Executive Commitment and Environmental Factors. Academy of Management Journal 42(1), 41-57.

Weber, J.: 1991, 'Adapting Kohlberg to Enhance the Assessment of Managers Moral Reasoning', Business Ethics Quarterly 1(3), 293-318.

Weick, K. E.: 1995, Sensemaking in Organizations (Sage, Thousand Oaks).

Wighton D.: 2007, 'Paulson Backs Efforts to Tackle Competitiveness Threat to Wall St.', Financial Times January 23, p. 5.

Zimbardo, P. G.: 2004, 'A Situationist Perspective on the Psychology of Evil: Understanding How Good People are Ttransformed into Perpetrators', in A. Miller (ed.), The Social Psychology of Good and Evil: Understanding our Capacity for Kindness and Cruelty (Guilford, New York), pp. 21-50.

Zimbardo, P. G.: 2007, The Lucifer Effect: Understanding How Good People Turn Evil (Random House, New York).

Zitzewitz, E.: 2003, 'Who Cares about Shareholders? Arbitrage-Proofing Mutual Funds', Journal of Law, Economics \& Organization 19(2), 245-280.

\author{
Guido Palazzo \\ University of Lausanne, \\ Internef, Lausanne, VD, 1003, Switzerland \\ E-mail: Guido.Palazzo@unil.ch
}

Lena Rethel

University of Warwick,

Department of Politics and International Studies (PAIS), Coventry CV4 7AL, United Kingdom E-mail:L.Rethel@warwick.ac.uk 